\title{
HIERARKI PERATURAN PERUNDANG-UNDANGAN NEGARA REPUBLIK INDONESIA SEBAGAI SUATU SISTEM
}

\author{
HASANUDDIN HASIM
}

\author{
Fakultas Syariah \\ Sekolah Tiggi Agama Islam Negeri (STAIN) Parepare \\ Jl.Laupe Kota Parepare, Sulawesi Selatan Indonesia \\ Email: hasanalhasim@gmail.com
}

\begin{abstract}
The State recognizes the supremacy of the constitution above all other laws and regulations, which is evident from the modification that requires a procedure that is more severe than the law-making. The 1945 Constitution of the Republic of Indonesia has been established as the basic law in the legislation and occupies the highest place in the hierarchy of Indonesian laws and regulations. Hierarchy of Regulation no. 10 of 2004 which has been amended into Law no. 12 of 2011 include the MPR Decree and the Presidential Decree which changed the word Decision to the Regulation, this complement the hierarchical suprmasi of Indonesian law as a State of law as the mandate of the Constitution.
\end{abstract}

\section{Keywords: Hierarchical, Legislation, Legal System}

ABSTRAK: Negara mengakui supremasi undang-undang dasar di atas segala peraturan perundangundangan lainnya, hal mana terbukti dari cara mengubahnya yang memerlukan prosedur yang lebih berat dari pada pembuatan undang-undang. UUD Negara Republik Indonesia Tahun 1945 telah ditetapkan sebagai hukum dasar dalam peraturan perundang-undangan dan menempati tempat tertinggi dalam hirarki peraturan perundang-undangan Indonesia. Hirarki Peraturan Perundang-undang No. 10 tahun 2004 yang telah dirubah menjadi Undang-Undang No. 12 tahun 2011 memasukkan TAP MPR dan Peraturan Presiden yang mengubah kata Keputusan menjadi Peraturan, hal ini melengkapi hirarkis suprmasi hukum Indonesia sebagai Negara hukum sebagai mana amanat UUD

Kata Kunci: Hirarkis, Peraturan Perundang-Undangan, Sistem Hukum

\section{LATAR BELAKANG}

Berdasarkan ketentuan Pasal 1 ayat (3) UUD 1945, "Negara Indonesia adalah negara hukum", Sebelum amandemen, pernyataan Indonesia sebagai negara hukum ditemukan dalam Penjelasan UUD
1945, "Indonesia ialah negara yang berdasar atas hukum (rechtstaat)". Dilihat dari segi bentuk negara dan sistem penyelenggaraan pemerintahan, Indonesia adalah negara kesatuan yang menganut 
desentralisasi. ${ }^{1}$ Disamping itu, Indonesia merupakan negara yang menganut ajaran negara kesejahteraan (verzogingstate, welfare state) dan dapat dikategorikan sebagai negara hukum demokratis. ${ }^{2}$ Dimana dalam setiap penyelenggaraan urusan pemerintahan haruslah berdasar pada hukum yang berlaku (wetmatigheid van bestuur).

Menurut ajaran Hans Kelsen, ${ }^{3}$ negara itu pada hakekatnya adalah merupakan Zwangsordnung, suatu tertib hukum atau tertib masyarakat yang mempunyai sifat memaksa, yang menimbulkan hak memerintah dan kewajiban tunduk. Oleh karena tertib hukum menjelma dalam bentuk peraturan-peraturan yang mengandung sanksi apabila dilanggar, sehingga membatasi kebebasan warga negara yang merupakan nilai fundamental dalam suatu negara.

Pada umumnya negara-negara mengakui supremasi undang-undang dasar

\footnotetext{
1 Dalam Pasal 1 ayat (1) UUD 1945 disebutkan, "Negara Indonesia ialah negara kesatuan yang berbentuk republik", dan dalam Pasal 18 ayat (1) ditegaskan bahwa "Negara Kesatuan Republik Indonesia dibagi atas daerah-daerah provinsi dan daerah provinsi itu dibagi atas kabupaten dan kota, yang tiap-tiap provinsi, kabupaten, dan kota mempunyai pemerintah daerah, yang diatur undang-undang.

2 Bagir Manan, Hubungan Pusat-Daerah Dalam Penyelenggaraan Otonomi Daerah, dikutip dari Ridwan, Hukum Administrasi di Daerah, (Yogyakarta: UII Press, 2009), hlm. 47.

${ }^{3}$ Lihat dalam Soehino, Ilmu Negara Edisi Kedua, Cetakan Ketiga (Yogyakarta: Liberty, 1993), hlm.191.
}

di atas segala peraturan perundangundangan lainnya, hal mana terbukti dari cara mengubahnya yang memerlukan prosedur yang lebih berat dari pada pembuatan undang-undang. Lebih lanjut K.C. Wheare mengemukakan, dengan menempatkan konstitusi pada kedudukan yang tinggi (supreme) ada semacam jaminan bahwa konstitusi itu akan diperhatikan dan ditaati dan menjamin agar konstitusi tidak akan dirusak dan diubah begitu saja secara sembarangan. Perubahannya harus dilakukan secara hikmat, penuh kesungguhan dan pertimbangan yang mendalam. Agar maksud ini dapat dilaksanakan dengan baik maka perubahannya pada umumnya mensyaratkan adanya suatu proses dan prosedur yang khusus atau istimewa.

Memang pembuatan undang-undang dasar didorong oleh kesadaran politik yang tinggi mengenai keperluan pengaturan penyelenggaraan pemerintahan negara sebaik mungkin. Baik sebagai kaidah hukum maupun sebagai pernyataan prinsip-prinsip dan cita-cita, UUD sebagaimana juga hukum perundangundangan lainnya, adalah theresultan of $a$ paralellogram of forces-political, economic, and social which operateat the 
time of its adoption. ${ }^{4}$ Perbedaan pandangan politik, ekonomi, dan sosial yang mempengaruhi pembentukan UUD, tidak akan terlepas dari perbedaan latar belakang sejarah, kebudayaan serta keyakinan yang hidup dalam masyarakat bangsa tersebut. Menurut Bryce, ${ }^{5}$ undang-undang dasar dibuat secara sadar sebagai perangkat kaidah fundamental yang mempunyai nilai politik tinggi dari jenis kaidah lain karena menjadi dasar bagi seluruh tata kehidupan negara. Dengan asumsi ini maka bagianbagian lain dari tata hukum harus sesuai atau tidak berlawanan dengan undangundang dasar.

Dalam hubungannya dengan Undang-Undang Dasar (UUD) atau konstitusi, Kelsen menyatakan bahwa UUD menduduki tempat tertinggi dalam hukum nasional, sebab itu merupakan landasan bagi sistem hukum nasional. Undang-Undang Dasar merupakan fundamental law. Untuk itu Hans Kelsen menunjuk hak menguji sebagai mekanisme "guarantees ofthe constitution". 6 Jadi

\footnotetext{
${ }^{4}$ Ni'matul Huda, Urgensi Judicial Review Dalam Tata Hukum Indonesia, Jurnal Hukum No. 1 Vol. 15 Januari 2008: 101-120, hlm. 1

${ }^{5}$ Dahlan Thaib, et.al.,Teori dan Hukum Konstitusi, Cetakan Ketiga, (Jakarta:Raja Grafindo Perkasa, 2003), hlm. 64.

${ }^{6}$ Hans Kelsen, General Theory of Law and State,Dikutip dari Ni'matul Huda, Urgensi Judicial Review Dalam Tata Hukum Indonesia, Jurnal Hukum No. 1 Vol. 15 Januari 2008: 101 - 120, hlm. 2 .
}

dapat dikatakan bahwa hak menguji merupakan konsekuensi dari konstitusi tertulis, atau yang oleh Kelsen disebut konstitusi dalam arti formal, atau konstitusi dalam arti sempit.

UUD Negara Republik Indonesia Tahun 1945 telah ditetapkan sebagai hukum dasar dalam peraturan perundangundangan dan menempati tempat tertinggi dalam hirarki peraturan perundangundangan Indonesia. Akan tetapi pada kenyataannya banyak peraturan dengan derajat lebih rendah dari UUD 1945 justru bertentangan dengan peraturan di atasnya. Sebagai contoh misalnya, undang-undang yang berkaitan dengan ekonomi selalu digembor-gemborkan bahwa menganut sistem ekonomi kerakyatan, padahal dalam isinya baik secara langsung maupun tidak langsung justru cenderung menggunakan sistem ekonomi liberal yang sangat merugikan rakyat kecil. Inilah yang menarik untuk dikaji lebih lanjut bagaimana hierarki peraturan perundangundangan 'bekerja' sebagai sebuah sistem yang tidak terpisahkan dan saling menguatkan antara peraturan yang satu dengan yang lain.

Dari latar belakang di atas dapat diambil permasalahan yang akan dikaji lebih lanjut, yaitu: bagaimana hierarki peraturan perundang-undangan 'bekerja' 
sebagai sebuah sistem yang tidak terpisahkan.

\section{METODE PENULISAN}

\section{Tipe Penelitian}

Dalam penelitian ini penulis menggunakan jenis penelitian hukum normatif, yaitu suatu prosedur penelitian ilmiah untuk menemukan kebenaran berdasarkan logika keilmuan hukum dari sisi normatif

\section{Jenis dan Sumber Data}

Sumber data dalam tulisan ini bersumber dari data sekunder yakni data yang diperoleh dari data-data, buku dan menggunakan bahan hukum primer yakni dari peraturan perundangan-undangan; lalu kedua bahan Hukum Sekunder adalah data yang diperoleh dari hasil studi dokumendokumen, literature maupun sumber bacaan lainnya yang dipandang relevan dengan penulisan; dan ketiga Bahan hukum tersier yang memberikan informasi tentang bahan hukum primer dan bahan hukum sekunder.

\section{Teknik Pengumpulan Data}

Adapun teknik pengumpulan data melalui cara:

Studi Kepustakaan, Merupakan tehnik pengumpulan data sekunder yakni sumber dta bukan dari orang secara langsung tapi data-data atau dari bahan Hukum primer semisal peraturan perundang-undangan, buku-buku, dokumen-dokumen dan bahan pustaka atau bahan tertulis lainnya yang berhubungan dengan suatu peristiwa atau aktifitas tertentu yang berkaitan dengan perumusan masalah dalam penelitian yang akan dijawab.

\section{PEMBAHASAN}

\section{Pengertian dan Sifat-Sifat Sistem}

Secara semantik, istilah sistem diadopsi dari bahasa Yunani yaitu "systema" yang diartikan sebagai keseluruhan yang terdiri dari macammacam bagian. Scoderbek ${ }^{7}$ menyatakan bahwa sistem adalah seperangkat tujuan yang bersama-sama dengan interrelasi diantara tujuan dan diantara atributatributnya dihubungkan satu sama lainnya, serta dihubungkan dengan lingkungan sedemikian rupa sehingga membentuk keseluruhan.

Menurut Prof. Pamuji ${ }^{8}$ yang dimaksud dengan sebuah sistem adalah:

Pertama, Suatu kebulatan/ keseluruhan kompleks atau teroganisasi, suatu himpunan atau perpaduan hal-hal atau

\footnotetext{
${ }^{7}$ Erna Tri Rusmala, Dasar-Dasar Ilmu Hukum, (Yogyakarta: Laboratorium Hukum Universitas Widya Mataram, 2008), hlm. 94

${ }^{8}$ Dikutip dari Bewa Ragawino, Sistem Peraturan Perundang-Undangan Negara Republik Indonesia, (Bandung: Fakultas Ilmu Sosial dan Ilmu Politik Universitas Padjadjaran, 2005), hlm. 1
} 
bagian yang membentuk suatu kebulatan atau keseluruhan yang kompleks atau utuh.

Kedua, Suatu kebulatan atau keseluruhan yang utuh dimana didalamnya terdapat komponen-komponen yang pada gilirannya, merupakan sistem tersendiri yang mempunyai fungsi masing-masing, saling berhubungan satu sama lain menurut pola, tata, atau norma tertentu dalam rangka mencapai suatu tujuan.

Sedangkan Remington dan Ohlin ${ }^{9}$ menjabarkan bahwa sistem adalah suatu jaringan dari prosedur-prosedur yang berhubungan satu sama lainmenurut skema atau pola yang bulat untuk menggerakkan suatu fungsi yang utama darisuatu usaha atau urusan. Dimana pengertian sistem itu sendiri mengandung implikasi terhadap suatu proses interaksi yang dipersiapkan secara rasional dan dengan cara efisien untuk memberikan hasil tertentu dengan segala keterbatasannya.

Sedangkan menurut Sri Sumantri ${ }^{10}$ sistem adalah sekelompok bagian-bagioan yang bekerja bersama-sama untuk melakukan sustu maksud, apabila salah satu bagian rusak atau tidak dapat menjalankan tugasnya, maka maksud yang hendak dicapai tidak akan terpenuhi atau

\footnotetext{
${ }^{9}$ Lihat dalam Setya Wahyudi, Implementasi Ide Diversi Dalam Pembaruan Sistem Peradilan Pidana Anak di Indonesia, (Yogyakarta: Genta Publishing, 2011), hlm. 35-36.

${ }^{10}$ Sri Soemantri, Prosedur dan Sistem Perubahan Konstitusi, (Bandung: Alumni, 2006), hlm. 14.
}

setidak-tidaknya sistem yang telah terwujud akan mendapat gangguan.

Dalam kamus besar bahasa Indonesia $^{11}$ sistem adalah sekelompok bagian-bagian (alat dan sebagainya) yang bekerja bersama-sama untuk melakukan sesuatu maksud. Menurut Musaraf sistem adalah : pertama, Suatu sarana yang menguasai keadaan dan bekerja agar dalam menjalankan tugasnya dapat teratur. Kedua, Suatu tatanan dari hal-hal yang saling berkaitan dan berhubungan sehingga membentuk satu kesatuan dan satu keseluruhan. Suatu sistem adalah seperangkat komponen, elemen, unsur atau sub sistem dengan segala atributnya yang satu sama lain salaing berkaitan, pengaruh mempengaruhi dan saling tergantung, sehingga keseluruhannya merupakan suatu kesatuan yang terintegrasi serta mempunyai peranan atau tujuan tertentu.

Dari pengertian di atas, maka sistem peraturan Perundang-undangan adalah satu kesatuan dari seluruh peraturan perundangundangan yang satu sama lain saling berhubungan dan merupakan sub-sub sistem yang terintegrasi dalam satu kesatuan yang bulat dan tidak bertentangan antara satu dengan yang lainnya.

Peraturan Perundang-undangan sebagai suatu sistem terdiri dari sub-sub

\footnotetext{
${ }^{11}$ Kamus Besar Bahasa Indonesia (KBBI) Edisi Kedua, (Jakarta: Balai Pustaka, 1994), hlm. 203.
} 


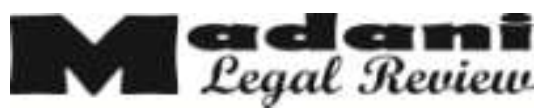

sistem, makasifat-sifat dari pada sistem atau cirri-cirinya adalah : pertama, Bersifat abstrak artinya tidak berwujud. Kedua, Merupakan hasil buatan dari manusia yang terencana. Ketiga,Terbuka/ gejala sosial yang mendapatkan pengaruh social. Keempat, Hidup/ diberlakukan dan terakhir Kompleks, karena didalamnya banyak subsub sistem dan saling berhubungan satu dengan yang lainnya.

Peraturan Perundang-undangan pada dasarnya merupakan proses penyelenggaraan Negara/ pemerintah dalam rangka tercapainya tata tertib dalam bernegara. Peraturan Perundang-undangan merupakan alat atau sarana untuk tercapinya cita-cita dan tujuan Negara yaitu Kesejahteraan Masyarakat (Welfare state). Untuk mewujudkan cita-cita dan tujuan Negara Republik Indonesia harus didasarkan pada: ${ }^{12}$

Pertama, Proklamasi Kemerdekaan 17 agustus 1945, yang merupakan dasar hukum terbentuknya Negara Kesatuan Republik Indonesia (NKRI). Kedua, Filsafat Bangsa/ Dasar Negara yaitu Pancasila yang merupakan Landasan Idiil dan Sumber dari segala sumber hukum.. Dan terakhir Undang-Undang Dasar 1945 yang merupakan Landasan Konstitusional

\footnotetext{
${ }^{12}$ Bewa Ragawino,Sistem........ Op.cit., hlm. 3.
}

bagi setiap peraturan Perundang-undangan yang berlaku di negara ini.

\section{Hirarki Peraturan Perundang- undangan Indonesia}

Mengenai tata urutan peraturan perundang-undangan diatur dalam UU No. 10 Tahun 2004 dan sekaligus merupakan koreksi terhadap pengaturan hirarki peraturan perundang-undangan yang selama ini pernah berlaku yaitu TAP MPR No. XX Tahun 1966 dan TAP MPR No. III Tahun 2000. Untuk lebih jelasnya Tata Urutan Peraturan Perundang-Undangan tersebut adalah :

2.1 TAP MPR No. XX Tahun 1966

\subsubsection{UUD RI 1945}

\subsubsection{TAP MPR}

2.1.3 UU/Perpu

2.1.4 Peraturan Pemerintah

2.1.5 Keputusan Presiden

2.1.6 Peraturan-peraturan pelaksanaan lainnya, seperti : Peraturan Menteri dan Instruksi Menteri

2.2 TAP MPR No. III Tahun 2000

2.1.1 UUD RI 1945

2.1.2 TAP MPR RI

2.1.3 UU

2.1.4 Perpu

2.1.5 Peraturan Pemerintah

2.1.6 Keputusan Presiden

2.1.7 Peraturan Daerah

2.3 Undang-Undang No. 10 Tahun 2004

2.3.1 UUD RI 1945 


\section{N Regal Revieu}

\subsubsection{UU/Perpu}

\subsubsection{Peraturan Pemerintah}

2.3.4 Peraturan Presiden

2.3.5 Peraturan Daerah, seperti : pertama, Perda Provinsi dibuat DPRD Provinsi dengan Gubernur, kedua, Perda Kabupaten/ Kota dibuat oleh DPRD Kabupaten/ Kota bersama Bupati/Walikota dan Peraturan Desa/ Peraturan yang setingkat dibuat oleh BPD atau nama lainnyabersama dengan Kepala Desa atau nama lainnya.

2.4 Undang-undang No. 12 Tahun 2011

\subsubsection{UUD RI 1945}

\subsubsection{TAP MPR}

\subsubsection{UU/Perpu}

\subsubsection{Peraturan Pemerintah}

\subsubsection{Peraturan Presiden}

\subsubsection{Peraturan Daerah}

Dengan Undang-Undang No. 12 Tahun 2011 ini, maka TAP MPR Nomor XX Tahun 1966 dan TAP MPR No. III Tahun 2000 dicabut dan tidak berlaku lagi, karena tidak sesuai dengan prinsip demokrasi dan prinsip-prinsip negara hukum yang antara lain :

Pertama, Soal Ketetapan MPR/ MPRS, karena Ketetapan MPR/ MPRS tidak tepat dikatagorikan sebagai peraturan perundang-undangan. Kedua, Soal Perpu, karena kedudukannya dibawah Undang-
Undang, menurut TAP MPR No. III Tahun 2000, soal ini tidak tepat dan menempatkan kedudukannya sama dengan Undang-Undang dalam UU No. 10 Tahun 2004.

Ketiga, Keputusan Menteri yang diatur dalam TAP MPRS No. XX Tahun 1966. Keputusan Menteri tersebut tidak mempunyai dasar yuridis. keempat, Kata "dan lain-lain" yang tersebut dalam dalam TAP MPRS No. XX Tahun 1966 sempat membingungkan karena dapat menimbulkan berbagai penafsiran

Kelima, Soal "Instruksi" yang dimasukkan dalam golongan peraturan perundang-undangan adalah soal yang tidak tepat. Dan kelima, Menempatkan UUD 1945 sebagai peraturan perundangundangan adalah suatu hal yang tidak tepat, karena UUD 1945 merupakan norma dasar atau kaidah-kaidah dasar bagi pengaturan Negara dan merupakan landasan filosofis dari Negara yang memuat aturan-aturan pokok Negara, sedangkan yang dimaksud dengan peraturan perundang-undangan adaalah dimulai dari Undang-Undang ke bawah sampai dengan Perda yang merupakan peraturan-peraturan pelaksanaan.

\section{Hierarki Peraturan Perundang- Undangan Sebagai Sistem}

Dalam teori perundang-undangan terdapat beberapa asas dalam proses 
pembentukan sebuah undang-undang, misalnya: asas lex specialis derogat legi generali, asas lex superior derogat legi inferiori, yang pada intinya aturan yang khusus maupun berkedudukan lebih tinggi lebih diutamakan daripada aturan yang umum dan berkedudukan lebih rendah. Dalam hal-hal tertentu asas lex posterior derogat legi priori yang berarti aturan yang baru lebih dimenangkan daripada aturan yang lama. ${ }^{13}$

Sedangkan mengenai ajaran tentang tata urutan peraturan perundang-undangan tersebut mengandung beberapa prinsip berikut :

Pertama, Peraturan perundangundangan yang lebih tinggi kedudukannya dapat dijadikan landasan atau dasar hukum bagi peraturan perundang-undangan yang lebih rendah atau berada dibawahnya.

Kedua, Peraturan perundangundangan tingkat lebih rendah harus bersumber atau memiliki dasar hukum dari peraturan perundang-undangan yang tingkat lebih tinggi.

Ketiga, Isi atau muatan peraturan perundang-undangan yang lebih rendah tidak boleh menyimpang atau bertentangan dengan peraturan perundang-undangan yang lebih tinggi tingkatannya.

Keempat, Suatu peraturan perundang-undangan hanya dapat dicabut,

\footnotetext{
${ }^{13}$ Erna Tri Rusmala,.Loc.cit.
}

diganti atau diubah dengan peraturan perundang-undangan yang lebih tinggi atau paling tidak dengan yang sederajat.

Kelima, Peraturan perundangundangan yang sejenis apabila mengatur materi yang sama, peraturan yang terbaru harus diberlakukan walaupun tidak dengan secara tegas dinyatakan bahwa peraturan yang lama itu dicabut. Selain itu, peraturan yang mengatur materi yang lebih khusus harus diutamakan dari peraturan perundangundangan yang lebih umum.

Konsekuensi penting dari prinsipprinsip di atas adalah harus diadakannya mekanismeyang menjaga dan menjamin agar prinsip tersebut tidak disimpangkan atau dilanggar. Mekanismenya yaitu ada system pengujian secara yudisial atas setiap peraturan perundang-undangan, kebijakan, maupun tindakan pemerintah lainnya terhadap peraturan perundangundangan yang lebih tinggi tingkatannya atau tingkat tertinggiyaitu UUD. Tanpa konsekuensi tersebut, tata urutan tidak akan berarti. Hal ini dapatmenyebabkan peraturan perundang-undangan yang tingkatnya lebih rendah dapat tetapberlaku walaupun bertentangan dengan peraturan perundang-undangan tingkat lebih tinggi.

Undang-Undang Nomor 12 Tahun 2011 menetapkan Tata Urutan Peraturan Perundang-Undangan Republik Indonesia. Pada pasal 7, DPR dan pemerintah telah 
menyetujui Rancangan Undang-Undang tentang Pembentukan Peraturan Perundang-Undangan menjadi UndangUndang (UU No. 12 Tahun 2011). Undang-Undang ini menegaskan bahwa Pancasila merupakan sumber dari segala sumber hukum Negara. UUD Negara Republik Indonesia Tahun1945 merupakan hukum dasar dalam peraturan perundangundangan. Undang-undang ini juga memerintahkan untuk menempatkan UUD Negara Republik Indonesia Tahun 1945 dalam Lembaran Negara Republik Indonesia. Penempatan UUD Negara Republik Indonesia Tahun 1945 dalam Lembaran Negara Republik Indonesia tidak merupakan dasar pemberlakuannya. Disamping itu, diatur mengenai jenis dan hierarki peraturan perundang-undangan (Pasal 7).

Sebelumnya hierarki peraturan perundang-undangandituangkan dalam produk hukum Ketetapan MPR/MPRS sebagaimana telah dibahas diatas. Adapun jenis dan hierarki peraturan perundangundangan yang diatur dalam Pasal 7 Undang-Undang tersebut adalah sebagai berikut :

\begin{tabular}{|c|}
\hline HIERARKI PERATURAN \\
PERUNDANG-UNDANGAN \\
MENURUT UU NO. 12 TAHUN 2011 \\
\hline a. \\
UUD Negara Republik Indonesia \\
Tahun 1945
\end{tabular}

\begin{tabular}{|l}
\hline b. TAP MPR \\
c. Undang-Undang/ Peraturan \\
Pemerintah Pengganti UU \\
d. Peraturan Pemerintah \\
e. Peraturan Presiden \\
f. Peraturan Daerah \\
1. Perda Provinsi \\
2. Perda Kabupaten/ Kota \\
3. Perdes/ Perturan yang \\
Setingkat
\end{tabular}

Dalam BAB III, diatur mengenai materi muatan peraturan perundangundangan dariPasal 8 sampai dengan Pasal 14. Menurut UU tersebut, materi muatan yang harus diaturdengan undang-undang berisi hal-hal berikut :

Pertama, Mengatur lebih lanjut ketentuan UUD Negara Republik Indonesia Tahun 1945 yang meliputi :Hakhak asasi manusia, Hak dan kewajiban warga Negara, Pelaksanaan dan penegakkan kedaulatan Negara serta pembagian kekuasaan Negara, Wilayah Negara dan pembagian daerah, Kewarganegaraan dan kependudukan, dan Keuangan Negara.

Kedua, Diperintahkan oleh suatu undang-undang untuk diatur dengan undang-undang Materi muatan Perpu sama dengan materi muatan undang-undang. Adapun materi muatan peraturan pemrintah berisi materi untuk menjalankan undang-undang sebagaimana mestinya. 
Materi muatan peraturan Presiden berisi materi yang diperintahkan oleh undangundang atau materi untuk melaksanakan paraturan pemerintah. Materi mauatan peraturan daerah adalah seluruh materi muatan dalamrangka penyelenggaraan otonomi daerah dan tugas pembantuan, dan menampungkondisi khsuus daerah, serta penjabaran labih lanjut peraturan perundang-undangan yang lebih tinggi. Materi muatan peraturan desa / yang setingkat adalah seluruh materi dalam rangka penyelenggaraan urusan desa atau yang setingkat serta penjabaran lebih lanjut peraturan perundang-undangan yang lebih tinggi. Materi muatan mengenai ketentuan pidana hanya dapat dimuat dalam undangundang dan peraturan daerah.

\section{KESUMPULAN}

Pemaparan di atas dapat diambil kesimpulan, bahwa sebagai sebuah sistem, hierarki perundang-undangan di Indonesia tidak bisa dipisahkan antara satu peraturan dengan peraturan yang lain. Hal ini dikarenakan dalam muatan peraturan yang lebih rendah tidak boleh bertentangan dengan peraturan yang lebih tinggi.

Pancasila sebagai landasan ideologi bangsa harus menjadi sumber dalam pembuatan peraturan perundang-undangan.

Oleh karena itu sistem Peraturan Perundang-Undangan yang dikembangkan di Indonesia harus merupakan penjabaran dan pengalaman dari kelima sila dari Pancasila secara bulat dan utuh, dan diselenggarakan dalam rangka pelaksanaan Sistem Perundang-Undangan Indonesia berdasarkan Undang-Undang Dasar 1945.

\section{DAFTAR PUSTAKA}

Azhary, Tahir. Negara Hukum. Jakarta: Bulan Bintang, 1992.

Kusumohamidjojo, Budiono. Ketertiban yang Adil, Problematika Filsafat Hukum. Jakarta: Grasindo, 1999

Ma'arif, Ahmad Syafii, lslam dan Pancasilan Sebaga Dasar Negara Studi Tentang Perdebatan Dalam Konstituante. Jakarta: Pustaka LP3ES Indonesia, 2006.

Ragawino, Bewa. Sistem Peraturan Perundang-Undangan Negara Republik Indonesia. Bandung: Fakultas Ilmu Sosial Dan Ilmu Politik Universitas Padjadjaran, 2005.

Ridwan. Hukum Administrasi di Daerah. Yogyakarta: UII Press, 2009.

....., Hukum Administrasi Negara. Jakarta: PT. Rajawali Press, 2011.

Rusmala, Erna Tri. Dasar-Dasar Ilmu Hukum. Yogyakarta: Laboratorium Hukum Universitas Widya Mataram, 2008.

Soehino. Ilmu Negara Edisi Kedua. Yogyakarta: Liberty, 1993.

Soemantri, Sri. Prosedur dan Sistem Perubahan Konstitusi. Bandung: Alumni, 2006.

Thaib, Dahlan, et.al.,Teori dan Hukum Konstitusi. Jakarta: Raja Grafindo Perkasa, 2003. 


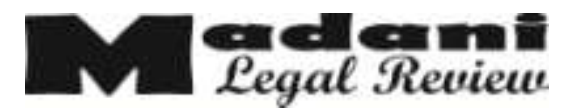

Wahyudi, Setya. Implementasi Ide Diversi Dalam Pembaruan Sistem Peradilan Pidana Anak di Indonesia. Yogyakarta: Genta Publishing, 2011.

Huda, Ni'matul. "Urgensi Judicial Review Dalam Tata Hukum Indonesia". Jurnal Hukum Vol. 15, No. 1 (Januari 2008) : $101-120$.
Issn cetak 2597.9353 II Issn online 2580-6319

Vol 1. No. 2 Desember 2017

Ketetapan MPR Nomor XX Tahun 1966.

Ketetapan MPR Nomor III Tahun 2000.

Undang-Undang Nomor 10 Tahun 2004 tentang Pembentukan Peraturan Perundang-Undangan.

Undang-Undang Nomor 12 Tahun 2011 tentang Pembentukan Peraturan Perundang-Undangan. 